\title{
Resolution of intussusception after spontaneous expulsion of an ileal lipoma per rectum: a case report and literature review
}

\author{
Bin Kang ${ }^{1}$, Qingkai Zhang ${ }^{1}$, Dong Shang ${ }^{1 *}$, Qingqiang Ni ${ }^{1}$, Faheem Muhammad ${ }^{1}$, Li Hou ${ }^{2}$ and Wenjun Cui ${ }^{3}$
}

\begin{abstract}
We herein report a case of spontaneous rectal expulsion of an ileal lipoma in a 65-year-old female patient who presented with recurrent attacks of subacute intestinal obstruction. During each episode, the patient developed severe abdominal pain and expelled a fleshy mass from her rectum. The fleshy mass was histopathologically diagnosed as a lipoma comprising fat cells, fibers, and blood vessels. Upon expulsion, the pain disappeared and the intussusception was immediately resolved. Colonoscopic examination revealed a $2.5-\mathrm{cm}$ diameter ulcerated lesion near the ileocecal valve, which was confirmed to be inflammation by pathological examination. A subsequent barium series revealed a normal colonic tract, and the patient remained completely symptom-free for 4 months after the incident. According to the relevant literature and our clinical experience, the treatment method for a lipoma depends on the patient's clinical manifestations and the size of the tumor. However, the various diagnostic and therapeutic modalities currently available continue to be debated; whether an asymptomatic lipoma requires treatment is controversial. When histopathological examination results allow for the exclusion of malignant lesions such as sarcoma, a lipoma can be resected surgically.
\end{abstract}

Keywords: Expulse, Intussusception, Lipoma, Self-healing, Small intestine

\section{Background}

Small intestinal tumors are extremely rare, accounting for only $1 \%$ to $2 \%$ of gastrointestinal tumors worldwide [1], and only around $30 \%$ of small intestinal tumors are benign. Lipoma, which is less prevalent than leiomyoma and adenoma, is the third most common primary benign tumor in the gut [2]. Small bowel tumors are rare entities that often present with nonspecific symptoms. When these tumors are $>2 \mathrm{~cm}$ in diameter, abdominal pain, hematochezia, and/or incomplete intestinal obstruction may appear. The lack of specific clinical manifestations makes it difficult to reach a definite preoperative diagnosis; sometimes the lipoma is even ignored after the development of an intussusception. Moreover, it is difficult to identify symptomatic patients with malignant tumors, which can consequently be misdiagnosed. Most intestinal lipomas

\footnotetext{
* Correspondence: dlydmed@sina.com

'Department of Acute Abdominal Surgery, First Affiliated Hospital, Dalian Medical University, No. 222 Zhongshan Road, Dalian 116011, Liaoning

Province, China

Full list of author information is available at the end of the article
}

are located in the distal ileum and colorectal region (mainly the right colon) and are rarely located in the stomach or proximal small intestine. Intestinal lipomas seldom deteriorate, and they do not relapse after cure.

Intussusception was reported for the first time in 1674 by Barbette of Amsterdam [3]. The development of intussusception in adults is extremely rare and has a variety of etiologies. Neoplasia is the most common cause and is present in approximately $65 \%$ of adult intussusception cases [4]. Adult patients with intussusception may or may not be symptomatic, and symptoms can be acute, intermittent, or chronic. Therefore, intussusception is difficult to diagnose. The manifestations of symptomatic lipoma include abdominal pain, hemorrhage, or incomplete intestinal obstruction. Because of their intramural location, lipomas can also serve as the leading point for intussusceptions. A correct and timely diagnosis is important to avoid complications such as bowel infarction and perforation secondary to obstruction.

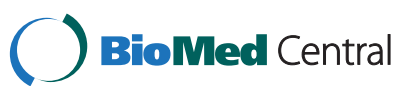

(c) 2014 Kang et al.; licensee BioMed Central Ltd. This is an Open Access article distributed under the terms of the Creative Commons Attribution License (http://creativecommons.org/licenses/by/4.0), which permits unrestricted use, distribution, and reproduction in any medium, provided the original work is properly credited. The Creative Commons Public Domain Dedication waiver (http://creativecommons.org/publicdomain/zero/1.0/) applies to the data made available in this article, unless otherwise stated. 


\section{Case presentation}

A 65-year-old woman was admitted to the emergency department with a 3-year history of intermittent abdominal pain that was exacerbated and accompanied by nausea for the past 5 days. The pain was moderate, paroxysmal, and colicky in nature; it was present mainly in the right lower quadrant and radiated to the back. She had no fever and reported intermittent defecation without nausea or vomiting. The patient had previously been seen at another hospital, where abdominal ultrasound and computed tomography $(\mathrm{CT})$ examination revealed either a smooth, well-circumscribed mass within the lumen of the bowel or an intussusception. Her symptoms improved after conservative treatment. Physical examination revealed tenderness in the right lower quadrant and a smooth, well-circumscribed mass of approximately $7.0 \times 5.0 \mathrm{~cm}$ was palpated in the epigastrium. Abdominal $\mathrm{CT}$ revealed a small bowel intussusception in the right epigastric region (Figure 1A and B).

The patient had no history of surgery, trauma, or other diseases. Laboratory test results showed a white blood cell count of $7.80 \times 10^{9} / \mathrm{L}$, a neutrophil level of $71.3 \%$, and a hemoglobin level of $104 \mathrm{~g} / \mathrm{L}$. Other examination results were normal. The preliminary diagnosis was considered to be an intestinal tumor with intussusception.

After admission, the patient was treated with oral therapy for bowel lubrication and experienced gradual relief of her abdominal pain. A vegetative mass was then extruded from the rectum when the patient defecated. However, it could not be completely discharged. Digital rectal examination revealed a well-circumscribed neoplasm with poor mobility in the center of the rectal lumen. A small amount of blood was present on the glove after digital examination. Abdominal CT showed a mass shadow in the ileocecal valve region with a maximum size of approximately $2.90 \times 3.22 \mathrm{~cm}$ (Figure 2A) and an expanded rectum with fat density and space within a shadow (Figure 2B). We actively enlarged the anus and administered a strong oral laxative. The patient then successfully defecated the mass. The mass was approximately $7.0 \times 4.5 \times 3.6 \mathrm{~cm}$ in size and of medium hardness; it had a smooth gray surface and a fine texture (Figure 3A). Microscopic examination showed fat cells, blood vessels, and fiber cells arranged in a leaf pattern, with no heterogeneous nucleus or seedless division in the submucosal layer. The pathologic diagnosis was a
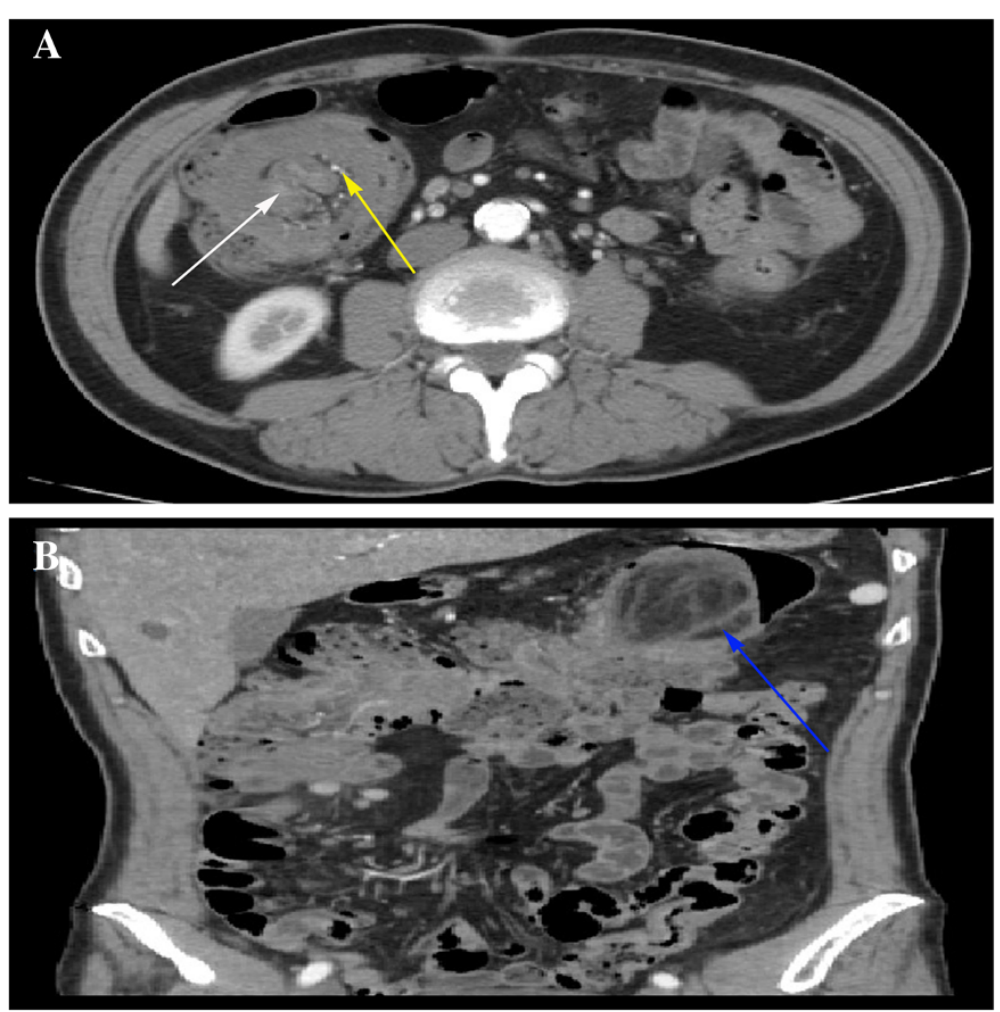

Figure 1 Transverse and coronary contrast-enhanced computed tomography (CECT) of the abdomen. (A) Transverse CECT showed the bowel intussusception (white arrow) entered the intestinal lumen on the right middle abdomen. Enhanced blood vessel (yellow arrow) also entered the intestinal lumen along with the bowel. (B) Coronary CECT showed that the tumor was located at the splenic flexure of the colon (blue arrow) and was accompanied by local intestinal expansion. 

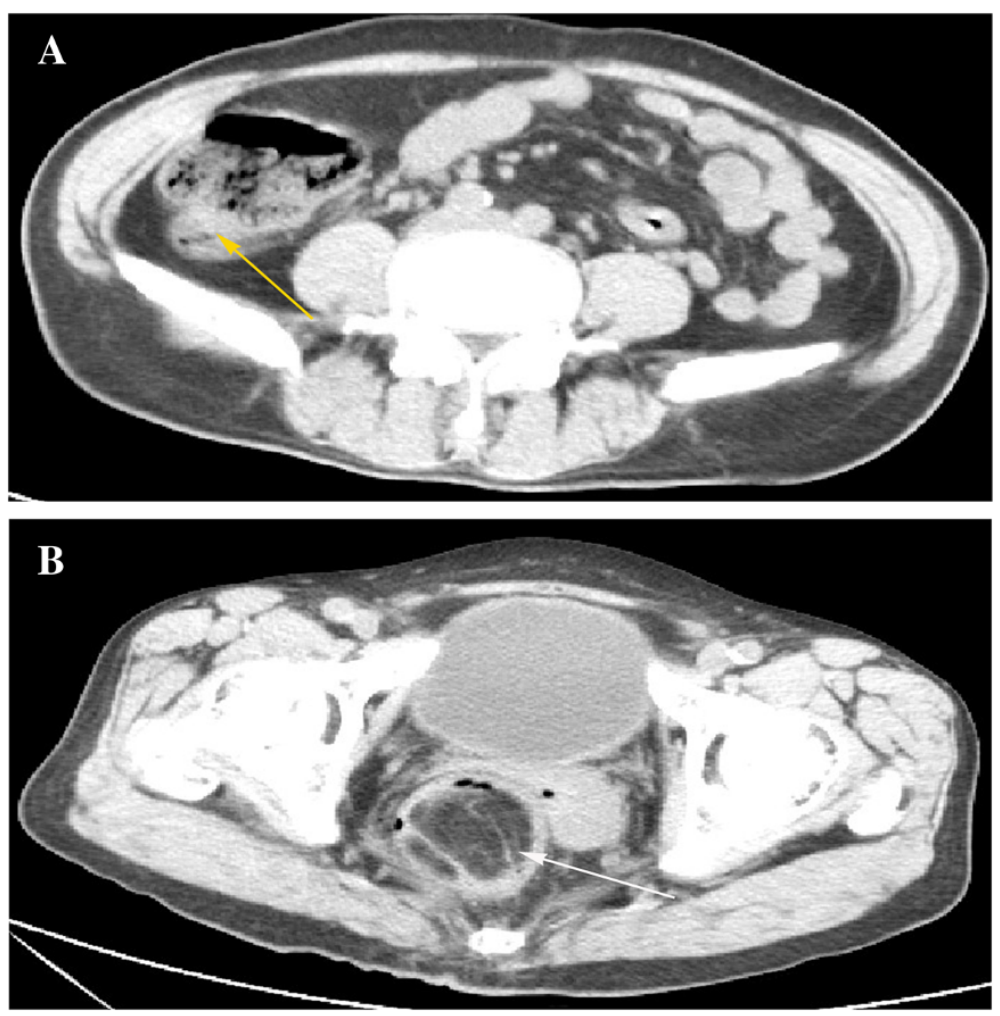

Figure 2 Computed tomography (CT) of the abdomen. (A) CT showed a mass shadow in the ileocecal valve with a maximum size of $2.90 \times 3.22 \mathrm{~cm}$ (yellow arrow). (B) CT showed the rectum expanded with fat density and space inside a shadow (white arrow).

bleeding submucosal lipoma with intestinal mucosal necrosis (Figure 3B).

After expulsion of the mass, the abdominal pain was completely relieved. Follow-up abdominal CT showed that the mass in the splenic flexure of the colon had disappeared and that the intussusception had been resolved. Colonoscopy showed an ulcerative lesion approximately $2.5 \mathrm{~cm}$ in diameter near the ileocecal valve that was surrounded by mucosal congestion (Figure 4A). Microscopic examination revealed regularly arranged glands; the epithelia were not atypical, but interstitial edema, eosinophils, and lymphocyte infiltration were present (Figure 4B). The pathologic diagnosis was inflammation of the ileocecal valve. Four months later, colonoscopy indicated that the inflammation of the ileocecal valve had healed and that the mucosa was intact. Subsequent capsule endoscopy and enteroscopy examination demonstrated no pathological changes.

\section{Discussion}

When the lipoma moved to the splenic flexure, as in this case, abdominal CT still showed signs of intussusception, indicating that the mass was connected to a pedicle. The long duration of the intussusception, the gravity of the lipoma, and the presence of intestinal peristalsis gave rise to ischemia, necrosis, and breakage of the pedicle.
Thus, the lipoma fell from the descending colon to the rectum, and the intussusception was resolved. After anal dilatation and catharsis treatment, the mass was spontaneously expelled. Abdominal CT and colonoscopy showed the mass shadow with an ulcerative lesion near the ileocecal valve as well as congestion of the surrounding mucosa. We consider that the mass shadow was caused by intestinal edema and thickening. The ulcerative lesion may have been caused by the impression of the mass when it fell to the ileocecal valve.

An intestinal lipoma is a benign tumor that can appear in any part of the gut. The terminal ileum is the most common location in the small intestine. There are three pathological types of intestinal lipomas. The submucosal type is the most common, accounting for more than $90 \%$ of intestinal lipomas, and grows within the submucosal layer, protruding into the lumen. The intermuscular type is located within the muscular layer. The subserosal type, which is asymptomatic, grows within the subserosal layer and protrudes out of the gut. Larger lipomas can be palpated as a smooth, movable abdominal lump. The tumor in our case was a submucosal lipoma. The patient spontaneously expelled the lipoma from her rectum before the development of intestinal ischemia and necrosis, and the intussusception was resolved spontaneously. 

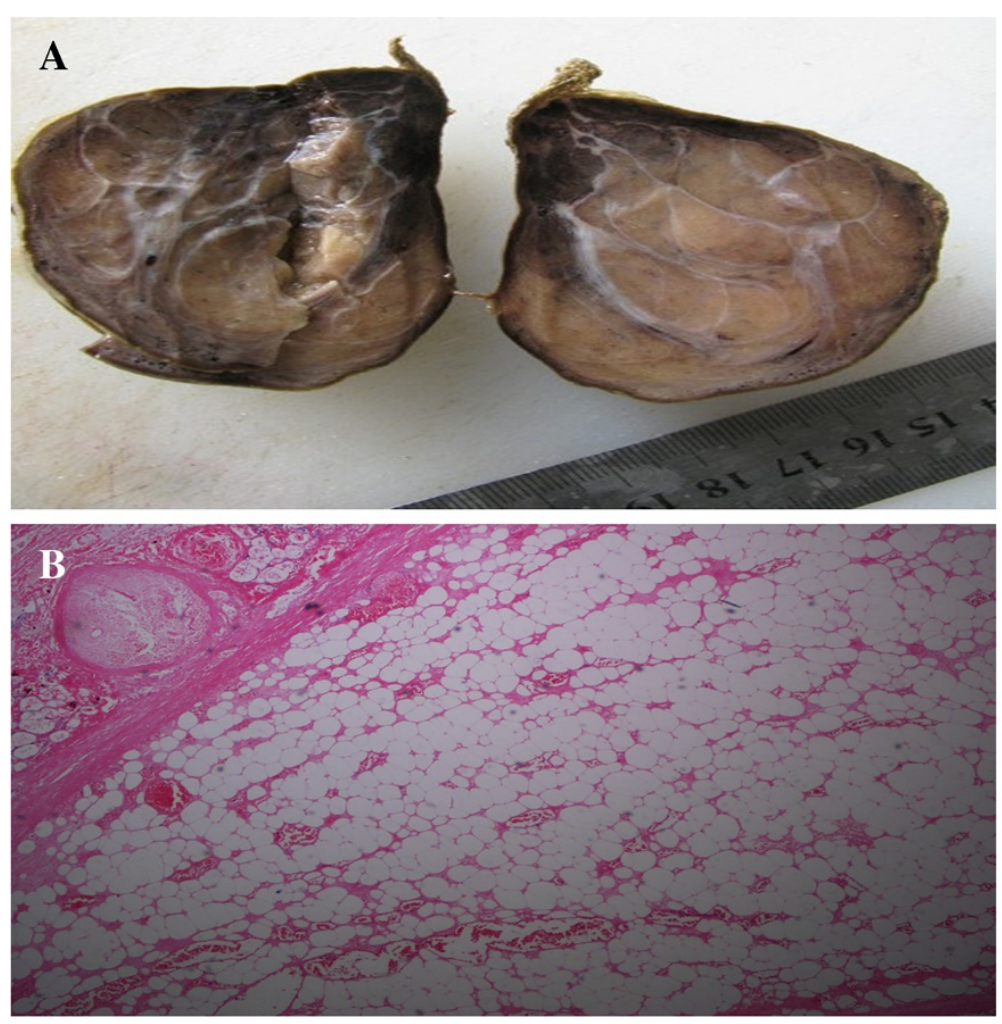

Figure 3 Tumor and histopathological features. (A) A mass section showed a gray surface and fine texture by formalin infiltration. (B) Microscopic examination showed fat cells, blood vessels, and fiber cells arranged in a leaf pattern, with no heterogeneous nucleus or seedless division in the submucosal layer (hematoxylin and eosin staining, $\times 40$ ).

Imaging examination and colonoscopy contribute to the preoperative diagnosis of intestinal lipomas. Intestinal lipomas can be diagnosed by conventional endoscopy, capsule endoscopy, and barium examination. The presence of a round filling defect with or without a pedicle in the lumen on barium enema examination or small intestinal barium enema intubation examination indicates a lipoma. Ultrasound is usually the first diagnostic modality chosen, especially when the lipoma is accompanied by intestinal intussusception. The characteristic ultrasound finding associated with an intussusception is the "target sign", in which the outermost layer represents the sheath, and the multilayer ring structure represents the invaginated intestinal segment. In some cases, ultrasonography can show a suborbicular nested mass with a clear boundary, low blood supply, and strong ultrasonic echo. These findings may indicate a lipoma. However, ultrasonography is generally limited to the demonstration of intestinal dilation and obstruction. CT is the most valuable diagnostic method for intestinal intussusception, and it can clearly reveal the typical characteristics of uniform tumor density, a clear border, no reinforcement, and fat (negative) density, allowing for a definite diagnosis [5]. Colonoscopy is also valuable in the diagnosis of intestinal lipoma. Microscopically, a lipoma is characterized as follows: i) it presents as an orange, smooth, submucosal mass protruding into the intestinal lumen with or without a pedicle; ii) the mass can immediately recover from local compression using biopsy forceps (the so-called "cushion sign"); and iii) after repeated biopsy of a certain part of the tumor, the submucosal adipose tissue is visible (termed "naked fat") [6]. However, endoscopy is of little significance for the diagnosis of intestinal lipoma.

We searched the PubMed database to gain a deeper understanding of lipomas in the small intestine. The following search terms were used: ((lipoma [MeSH Terms]) OR lipoma) AND ((intestine, small [MeSH Terms]) OR small intestine OR small bowel) AND (English [Language]) AND (intussusception [MeSH Terms]). Only 51 eligible articles were retrieved. We excluded articles that described secondary cases or the imaging characteristics of lipomas in the small intestine and only 27 articles remained [7-33] (Table 1).

According to the literature, most lipomas are asymptomatic. They may present as intestinal obstruction or hemorrhage [34]. The lack of specific clinical manifestations makes small intestinal lipomas difficult to diagnose. Their usual location in the small intestine is the ileum. The peak age of incidence is the sixth to seventh decade of life. Despite the development of imaging techniques, 

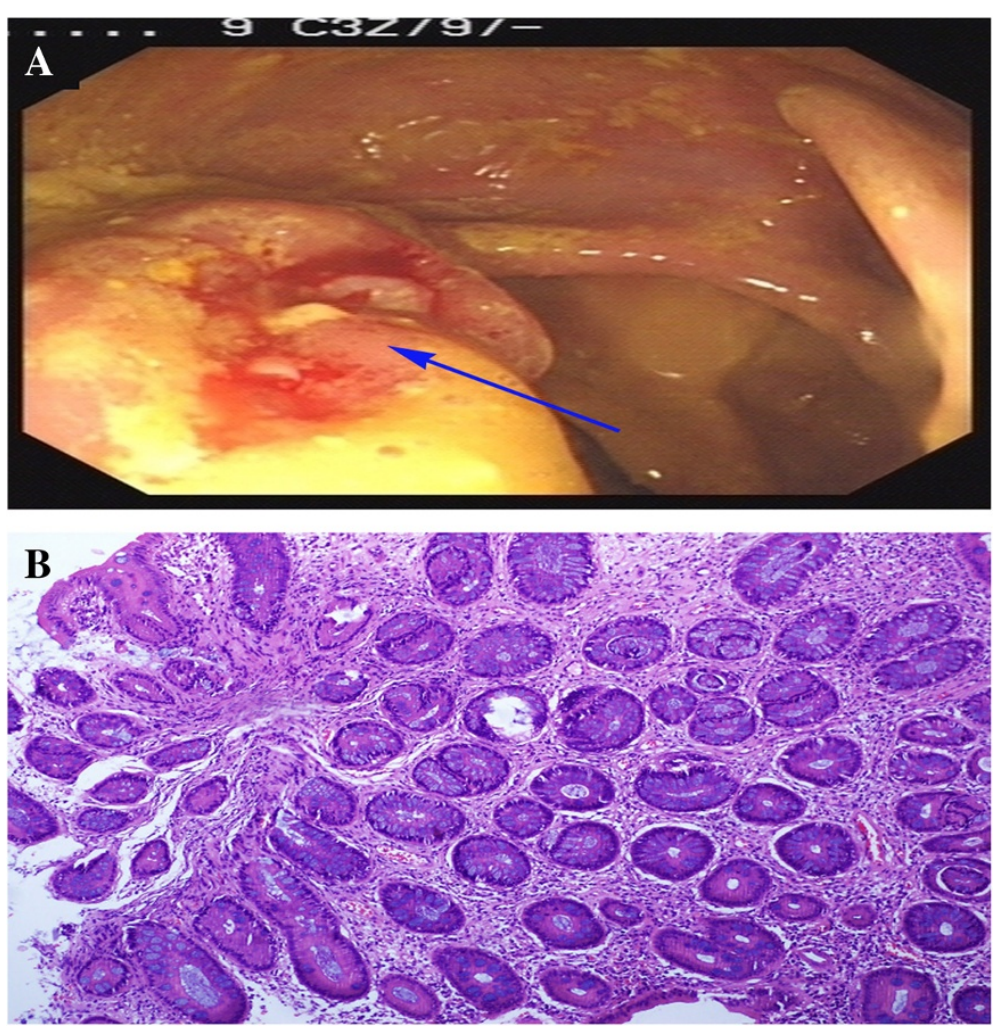

Figure 4 Colonoscopy and histopathological features. (A) Colonoscopy showed an approximately 2.5-cm diameter ulcerative lesion (blue arrow) near the ileocecal valve, surrounded by mucosal congestion. (B) Microscopic examination showed regularly arranged glands and epithelia with no atypia, but interstitial edema, eosinophils, and lymphocyte infiltration were present (hematoxylin and eosin staining, $\times 100$ ).

only $32 \%$ to $50 \%$ of cases are diagnosed preoperatively [35]. Intestinal lipomas $>2 \mathrm{~cm}$ in diameter can cause intussusception. The typical triad of abdominal pain, a sausage-shaped mass, and red jelly stools is seen in children, but rarely in adults. Adult intussusception is a very rare condition, accounting for only around 5\% of all intussusception cases and $1 \%$ of adult intestinal obstructions [36]. If a lipoma is $<2 \mathrm{~cm}$ in diameter, it can be resected via endoscopy. However, this method is risky for lipomas with no pedicle. Because fat is a poor conductor, it does not readily solidify after electric coagulation. Bleeding and deep tissue damage may occur. The electric current accumulation during coagulation greatly contributes to the risk of intestinal perforation. Therefore, local intestinal resection is the optimal treatment method. When a lipoma causes intussusception, the intestinal tract should be intraoperatively reset and the local intestine then resected. Otherwise, intestinal resection with anastomosis is feasible. If the condition cannot be diagnosed preoperatively, intraoperative pathological examination helps to determine the best surgical treatment method. In addition, some colonic lipomas are accompanied by colorectal cancer. The intestinal tract should be thoroughly explored during surgery to prevent misdiagnosis.
Definitive surgical resection remains the recommended treatment for adult intussusceptions due to the large proportion of structural causes and the relatively high incidence of malignancy. However, the most optimal surgical management technique remains controversial. Some investigators have stated that small bowel intussusceptions should be reduced only in patients in whom a definitive benign diagnosis has been made preoperatively and should be avoided in patients in whom resection may result in short-bowel syndrome [35]. All surgeons agree that intestinal resection is optimal if there are signs of irreversible bowel ischemia, inflammation, or suspected malignancy [37]. Otherwise, reduction is appropriate, especially when the small bowel is affected, because a considerable length of the bowel can be preserved, thereby preventing the development of short-bowel syndrome.

\section{Conclusions}

In summary, the treatment of intestinal lipoma depends on the clinical manifestations and the size of the tumor. Whether small asymptomatic lipomas need further treatment remains controversial. For symptomatic lipomas, operative resection can be performed to histopathologically exclude liposarcoma and malignant lesions. 
Table 1 Characteristics of reported cases of adult intussusception induced by a lipoma

\begin{tabular}{|c|c|c|c|c|c|c|c|c|c|c|}
\hline Case & Sex & $\begin{array}{l}\text { Age } \\
\text { (years) }\end{array}$ & Presentation & $\begin{array}{l}\text { Diagnostic } \\
\text { modality }\end{array}$ & Diagnosis & $\begin{array}{l}\text { Tumor } \\
\text { location }\end{array}$ & Size $(\mathrm{cm})$ & Treatment & Follow-up & Authors \\
\hline 1 & Female & 29 & Abdominal pain & US, CT & Angiolipoma & Ileum & $4.3 \times 2.5$ & $\begin{array}{l}\text { Exploratory } \\
\text { laparotomy }\end{array}$ & Uneventful & Esnakula K et al. [7] \\
\hline 2 & Male & 37 & $\begin{array}{l}\text { Abdominal pain, } \\
\text { constipation, and rectal } \\
\text { prolapse }\end{array}$ & Colonoscopy, CT & Colonic lipoma & Colon & 5.5 & Resection & Well & Pezzolla A et al. [8] \\
\hline 3 & Male & 75 & $\begin{array}{l}\text { Rectal bleeding and } \\
\text { anemia }\end{array}$ & Colonoscopy & Lipoma & Ileocecal valve & $2.7 \times 2.6 \times 2.2$ & $\begin{array}{l}\text { Endoscopic } \\
\text { resection }\end{array}$ & Well & Pezzolla A et al. [8] \\
\hline 4 & Female & 51 & $\begin{array}{l}\text { Abdominal pain, } \\
\text { constipation, and rectal } \\
\text { prolapse }\end{array}$ & Colonoscopy & Lipoma & Sigmoid colon & 10.0 & Mini-laparotomy & Well & Pezzolla A et al. [8] \\
\hline 5 & Male & 73 & $\begin{array}{l}\text { Abdominal pain, nausea, } \\
\text { vomiting, and } \\
\text { hematochezia }\end{array}$ & $\begin{array}{l}\text { Video capsule } \\
\text { endoscopy, CT }\end{array}$ & Lipoma & Mid-jejunum & 2.1 & Resection & Well & Lucas LC et al. [9] \\
\hline 6 & Female & 43 & $\begin{array}{l}\text { Nausea and upper } \\
\text { abdominal pain }\end{array}$ & MDCT, US & Submucosal lipoma & Small intestine & $2.4 \times 2.0 \times 2.0$ & Laparotomy & Uneventful & Ako E et al. [10] \\
\hline 7 & Female & 26 & $\begin{array}{l}\text { Abdominal pain and } \\
\text { vomiting }\end{array}$ & $\begin{array}{l}\text { Plain abdominal } \\
\text { film, } C T\end{array}$ & $\begin{array}{l}\text { Ectopic pancreas with } \\
\text { abundant fatty } \\
\text { infiltration }\end{array}$ & Small bowel & No exact data & Laparotomy & Unknown & Chuang MT et al. [11] \\
\hline 8 & Male & 68 & Abdominal bloating & DBE & $\begin{array}{l}\text { Multiple submucosal } \\
\text { lipomas }\end{array}$ & Jejunum & $\begin{array}{l}\text { From } 5.5 \times 6.0 \\
\text { to } 8.5 \times 7.5\end{array}$ & Resection & Well & Wan XY et al. [12] \\
\hline 9 & Male & 78 & $\begin{array}{l}\text { Constipation, nausea, and } \\
\text { vomiting }\end{array}$ & $\begin{array}{l}\text { Plain abdominal } \\
\text { film, } C T\end{array}$ & Submucosal lipoma & Ileum & 4.0 & Resection & Well & Di Saverio S et al. [13] \\
\hline 10 & Male & 45 & $\begin{array}{l}\text { Abdominal pain, nausea, } \\
\text { and vomiting }\end{array}$ & CT & Lipoma & Terminal ileum & 2.5 & $\begin{array}{l}\text { Laparoscopy and } \\
\text { resection }\end{array}$ & Well & Whitfield JD et al. [14] \\
\hline 11 & Female & 62 & $\begin{array}{l}\text { Abdominal pain, } \\
\text { alternating bowel habits, } \\
\text { and weight loss }\end{array}$ & US & Submucosal lipoma & Ileocecal valve & $7.0 \times 3.0 \times 2.5$ & $\begin{array}{l}\text { Laparotomy and } \\
\text { right } \\
\text { hemicolectomy }\end{array}$ & Well & Kuzmich S et al. [15] \\
\hline 12 & Male & 36 & $\begin{array}{l}\text { Epigastric pain, nausea, and } \\
\text { vomiting }\end{array}$ & X-ray, US, CT & Ileal lipoma & Ileum & $2.7 \times 2.7 \times 4.0$ & Resection & Well & Akagi I et al. [16] \\
\hline 13 & Female & 47 & $\begin{array}{l}\text { Nausea, vomiting, and } \\
\text { abdominal pain }\end{array}$ & CT & Submucosal lipoma & Small intestine & $3.0 \times 3.0$ & $\begin{array}{l}\text { Laparoscopy and } \\
\text { resection }\end{array}$ & Well & Lin MW et al. [17] \\
\hline 14 & Male & 54 & $\begin{array}{l}\text { Acute abdominal pain, } \\
\text { nausea, and vomiting }\end{array}$ & $\begin{array}{l}\text { Colonoscopy, } \\
\text { X-ray, CT }\end{array}$ & Lipoma & Ileum & No exact data & $\begin{array}{l}\text { Laparoscopy and } \\
\text { resection }\end{array}$ & Well & Oyen TL et al. [18] \\
\hline 15 & Female & 65 & $\begin{array}{l}\text { Abdominal cramps and } \\
\text { hematochezia }\end{array}$ & US, CT & Submucosal lipoma & Ileocecal & No exact data & $\begin{array}{l}\text { Laparotomy and } \\
\text { right } \\
\text { hemicolectomy }\end{array}$ & Well & Rathore MA [19] \\
\hline 16 & Male & 63 & $\begin{array}{l}\text { Mid abdominal pain, flatus, } \\
\text { and nausea }\end{array}$ & CT & Lipoma & Ileocecal valve & No exact data & Laparoscopy & Uneventful & McKay R [20] \\
\hline 17 & Male & 28 & $\begin{array}{l}\text { Cramps and abdominal } \\
\text { pain, vomiting, and } \\
\text { diarrhea }\end{array}$ & X-ray, CT & $\begin{array}{l}\text { Meckel's diverticulum } \\
\text { lipoma }\end{array}$ & Jejunum & 3.0 & Laparotomy & Uneventful & Ahmed HU et al. [21] \\
\hline
\end{tabular}


Table 1 Characteristics of reported cases of adult intussusception induced by a lipoma (Continued)

\begin{tabular}{|c|c|c|c|c|c|c|c|c|c|c|}
\hline 18 & Female & 20 & $\begin{array}{l}\text { Cramps and abdominal } \\
\text { pain }\end{array}$ & $C T, C E C T$ & Sub mucosal tumor & Small intestine & 1.8 & Laparotomy & Uneventful & Zissin R [22] \\
\hline 19 & Male & 40 & $\begin{array}{l}\text { Cramps and abdominal } \\
\text { pain, nausea, and vomiting }\end{array}$ & $\begin{array}{l}\mathrm{CT} \text {, MRI, small } \\
\text { intestinal barium } \\
\text { X-ray }\end{array}$ & Sub mucosal lipoma & Small bowel & $10.0 \times 3.0 \times 2.0$ & $\begin{array}{l}\text { Laparotomy and } \\
\text { reduction }\end{array}$ & Uneventful & Marino F et al. [23] \\
\hline 20 & Male & 55 & $\begin{array}{l}\text { Colicky epigastric pain, } \\
\text { nausea, and abdominal } \\
\text { distention }\end{array}$ & X-ray, US, CT & Lipoma & Terminal ileum & No exact data & Laparotomy & Well & Meshikhes AW et al. [24] \\
\hline 21 & Male & 72 & $\begin{array}{l}\text { Lack of appetite, early } \\
\text { satiety, and nausea }\end{array}$ & US, CT & Lipoma & Jejunum & $10.0 \times 5.0$ & Laparotomy & Uneventful & Mouës CM et al. [25] \\
\hline 22 & Male & 59 & Lower abdominal pain & $\begin{array}{l}\text { X-ray, US, } \\
\text { colonoscopy, EUS }\end{array}$ & Lipoma & Ileum & $2.7 \times 1.9 \times 1.9$ & Laparotomy & Unknown & Watanabe F et al. [26] \\
\hline 23 & Female & 80 & $\begin{array}{l}\text { Colicky upper abdominal } \\
\text { pain }\end{array}$ & CT & Lipoma & Jejunum & No exact data & Resection & Well & Ross GJ et al. [27] \\
\hline 24 & Female & 68 & $\begin{array}{l}\text { Periumbilical colicky pain, } \\
\text { nausea, and vomiting }\end{array}$ & X-ray, US, CT & Submucosal lipoma & Jejunum & 3.5 & Resection & Uneventful & Urbano J et al. [28] \\
\hline 25 & Male & 43 & $\begin{array}{l}\text { Crampy right upper } \\
\text { quadrant pain }\end{array}$ & X-ray, CT & $\begin{array}{l}\text { Multiple submucosal } \\
\text { lipomas }\end{array}$ & Small bowel & $1.0-4.0$ & Laparotomy & $\begin{array}{l}\text { Repeat laparotomy } \\
\text { due to necrotic } \\
\text { bowel }\end{array}$ & Gates LK Jr et al. [29] \\
\hline 26 & Male & 12 & $\begin{array}{l}\text { Cough, vomiting, and } \\
\text { intermittent epigastric pain }\end{array}$ & $\begin{array}{l}\text { US, ERCP, barium } \\
\text { meal, CT }\end{array}$ & Submucosal lipoma & Duodenal & $10.0 \times 6.0 \times 4.0$ & Laparotomy & Unknown & McGrath FP et al. [30] \\
\hline 27 & Male & 32 & Colicky abdominal pain & X-ray, barium meal & Lipoma & Small intestine & $8.0 \times 5.0$ & Conservative & Well & Misra SP et al. [31] \\
\hline 28 & Female & 42 & $\begin{array}{l}\text { Colicky periumbilical and } \\
\text { right upper quadrant pain }\end{array}$ & Barium enema, CT & Lipoma & Ileocecal valve & 3.0 & Laparotomy & Unknown & Donovan AT et al. [32] \\
\hline 29 & Male & 60 & Melena & Barium enema & Lipoma & Terminal ileum & $2.0 \times 3.0 \times 4.0$ & Resection & Unknown & Schnur MJ et al. [33] \\
\hline 30 & Female & 40 & Rectal bleeding & Barium enema & Submucosal lipoma & Terminal ileum & 6.0 & Resection & Unknown & Schnur MJ et al. [33] \\
\hline 31 & Male & 65 & Small bowel obstruction & Barium enema & $\begin{array}{l}\text { Malignant carcinoid } \\
\text { tumor }\end{array}$ & Terminal ileum & $0.5 \times 1.5 \times 3.0$ & Resection & Unknown & Schnur MJ et al. [33] \\
\hline 32 & Male & 75 & Cramp and abdominal pain & Barium enema & Lipoma & Terminal ileum & 5.0 & None & Unknown & Schnur MJ et al. [33] \\
\hline 33 & Female & 74 & Rectal bleeding & Barium enema & Lipoma & Terminal ileum & 1.0 & None & Well & Schnur MJ et al. [33] \\
\hline
\end{tabular}


Laparoscopic operative resection is superior to the traditional open operation. In the presence of complications such as acute intestinal obstruction, intussusception, or massive hemorrhage, operative treatment is recommended. In patients with intestinal ischemia, necrosis, or suspected malignancy, intestinal resection and anastomosis is feasible. Otherwise, reduction is appropriate and prevents the development of short-bowel syndrome.

In this paper, we have described a case involving a lipoma in the terminal ileum. Ultrasonographic and wholeabdomen CT examination showed that the lipoma had caused an ileocolic intussusception and incomplete intestinal obstruction. After the onset of the ileocecal intussusception, the site slowly expanded toward the ascending colon, transverse colon, and splenic flexure of the colon. The lipoma finally fell to the rectum, and intussusception resolved spontaneously.

\section{Consent}

Written informed consent was obtained from the patient for publication of this case and for the accompanying images.

\section{Abbreviations}

CECT: Contrast-enhanced computed tomography; CT: Computed tomography; DBE: Double-balloon endoscopy; ERCP: Endoscopic retrograde cholangiopancreatography; EUS: Endoscopic ultrasonography; MDCT: Multidetector row computed tomography; MRI: Magnetic resonance imaging; US: Ultrasonography.

\section{Competing interests}

All authors have made substantive contributions to the study, and are in agreement with the conclusions of the study. Furthermore, there are no financial competing interests.

\section{Authors' contributions}

BK and QZ searched the database, selected the articles, and wrote the manuscript. FM supervised the writing of the manuscript. QN, LH, and WC managed the figures. DS supervised the methodology, the selection of the articles, and the writing of the manuscript and is the corresponding author of the paper. All authors have read and approved the final manuscript.

\section{Authors' information}

The English in this document has been checked by at least two professional editors, both native speakers of English. For a certificate, please see: http:// www.textcheck.com/certificate/p5Hkrp.

\section{Acknowledgments}

We thank Prof. Dong Shang for assisting in the preparation of this manuscript.

\section{Author details}

${ }^{1}$ Department of Acute Abdominal Surgery, First Affiliated Hospital, Dalian Medical University, No. 222 Zhongshan Road, Dalian 116011, Liaoning Province, China. ${ }^{2}$ Department of Pathology, Dalian Medical University, No. 9 Lvshun South Road, Dalian 116044, Liaoning Province, China. ${ }^{3}$ Department of Radiology, First Affiliated Hospital, Dalian Medical University, No. 222 Zhongshan Road, Dalian 116011, Liaoning Province, China.

Received: 15 March 2014 Accepted: 20 April 2014

Published: 7 May 2014

\section{References}

1. Good CA: Tumors of the small intestine. Am J Roentgenol Radium Ther Nucl Med 1963, 89:685-705

2. Ashley SW, Wells SA Jr: Tumors of the small intestine. Semin Oncol 1988, 15:116-128.

3. Krasniqi AS, Hamza AR, Salihu LM, Spahija GS, Bicaj BX, Krasniqi SA Kurshumliu FI, Gashi-Luci LH: Compound double ileoileal and ileocecocolic intussusception caused by lipoma of the ileum in an adult patient: a case report. J Med Case Rep 2011, 5:452.

4. Warshauer DM, Lee JK: Adult intussusception detected at CT or MR imaging: clinical-imaging correlation. Radiology 1999, 212:853-860.

5. Franc-Law JM, Begin LR, Vasilevsky CA, Gordon PH: The dramatic presentation of colonic lipomata: report of two cases and review of the literature. Am Surg 2001, 67:491-494.

6. Notaro JR, Masser PA: Annular colon lipoma: a case report and review of the literature. Surgery 1991, 110:570-572.

7. Esnakula AK, Sinha A, Fidelia-Lambert M, Tammana VS: Angiolipoma: rare cause of adult ileoileal intussusception. BMJ Case Rep 2013. doi:10.1136/ bcr-2013-008921.

8. Pezzolla A, Lattarulo S, Caputi O, Ugenti I, Fabiano G, Piscitelli D: Colonic lipomas. Three surgical techniques for three different clinical cases. G Chir 2012, 33:420-422.

9. Lucas LC, Fass R, Krouse RS: Laparoscopic resection of a small bowe lipoma with incidental intussusception. JSLS 2010, 14:615-618.

10. Ako E, Morisaki T, Hasegawa T, Hirakawa T, Tachimori A, Nakazawa K, Yamagata S, Kanehara I, Nishimura S, Taenaka N: Laparoscopic resection of ileal lipoma diagnosed by multidetector-row computed tomography. Surg Laparosc Endosc Percutan Tech 2010, 20:e226-e229.

11. Chuang MT, Tsai KB, Ma CJ, Hsieh TJ: lleoileal intussusception due to ileal ectopic pancreas with abundant fat tissue mimicking lipoma. Am J Surg 2010, 200:e25-e27.

12. Wan $X Y$, Deng $T$, Luo HS: Partial intestinal obstruction secondary to multiple lipomas within jejunal duplication cyst: a case report. World J Gastroenterol 2010, 16:2190-2192.

13. Di Saverio S, Tugnoli G, Ansaloni L, Catena F, Biscardi A, Jovine E, Baldoni F: Concomitant intestinal obstruction: a misleading diagnostic pitfall. BMJ Case Rep 2010. doi: 10.1136/bcr.08.2009.2177.

14. Whitfield JD, Mostafa G: Images in clinical medicine. lleocecal intussusception. N Engl J Med 2009, 361:e55.

15. Kuzmich S, Connelly JP, Howlett DC, Kuzmich T, Basit R, Doctor C: lleocolocolic intussusception secondary to a submucosal lipoma: an unusual cause of intermittent abdominal pain in a 62-year-old woman. J Clin Ultrasound 2010, 38:48-51.

16. Akagi I, Miyashita M, Hashimoto M, Makino H, Nomura T, Tajiri T: Adult intussusception caused by an intestinal lipoma: report of a case. J Nippon Med Sch 2008, 75:166-170.

17. Lin MW, Chen KH, Lin HF, Chen HA, Wu JM, Huang SH: Laparoscopy-assisted resection of ileoileal intussusception caused by intestinal lipoma. J Laparoendosc Adv Surg Tech A 2007, 17:789-792.

18. Oyen TL, Wolthuis AM, Tollens T, Aelvoet C, Vanrijkel JP: Ileo-ileal intussusception secondary to a lipoma: a literature review. Acta Chir Belg 2007, 107:60-63.

19. Rathore MA, Andrabi SI, Mansha M: Adult intussusception-a surgical dilemma. J Ayub Med Coll Abbottabad 2006, 18:3-6.

20. McKay R: lleocecal intussusception in an adult: the laparoscopic approach. JSLS 2006, 10:250-253.

21. Ahmed HU, Wajed S, Krijgsman B, Elliot V, Winslet M: Acute abdomen secondary to a Meckel's lipoma. Ann R Coll Surg Engl 2004, 86:W4-W5.

22. Zissin R: Enteroenteric intussusception secondary to a lipoma: CT diagnosis. Emerg Radiol 2004, 11:107-109.

23. Marino F, Lobascio P, Martines G, Di Franco AD, Rinaldi M, Altomare DF: Double jejunal intussusception in an adult with chronic subileus due to a giant lipoma: a case report. Chir Ital 2005, 57:239-242.

24. Meshikhes AW, Al-Momen SA, Al Talaq FT, Al-Jaroof AH: Adult intussusception caused by a lipoma in the small bowel: report of a case. Surg Today 2005, 35:161-165.

25. Moues CM, Steenvoorde P, Viersma JH, van Groningen K, de Bruine JF: Jejunal intussusception of a gastric lipoma: a review of literature. Dig Surg 2002, 19:418-420.

26. Watanabe F, Honda S, Kubota H, Higuchi R, Sugimoto K, Iwasaki H, Yoshino G, Kanamaru H, Hanai H, Yoshii S, Kaneko E: Preoperative diagnosis of ileal 
lipoma by endoscopic ultrasonography probe. J Clin Gastroentero/ 2000, 31:245-247.

27. Ross GJ, Amilineni V: Case 26: Jejunojejunal intussusception secondary to a lipoma. Radiology 2000, 216:727-730.

28. Urbano J, Serantes A, Hernandez L, Turegano F: Lipoma-induced jejunojejunal intussusception: US and CT diagnosis. Abdom Imaging 1996, 21:522-524

29. Gates LK Jr, Keate RF, Smalley JJ Jr, Richardson JD: Macrodactylia fibrolipomatosis complicated by multiple small bowel lipomas and intussusception. J Clin Gastroenterol 1996, 23:241-242.

30. McGrath FP, Moote DJ, Langer JC, Orr W, Somers S: Duodenojejunal intussusception secondary to a duodenal lipoma presenting in a young boy. Pediatr Radiol 1991, 21:590-591.

31. Misra SP, Singh SK, Thorat VK, Gulati P, Malhotra V, Anand BS: Spontaneous expulsion per rectum of an ileal lipoma. Postgrad Med J 1988, 64:718-719.

32. Donovan AT, Goldman SM: Computed tomography of ileocecal intussusception: mechanism and appearance. J Comput Assist Tomogr 1982, 6:630-632

33. Schnur MJ, Seaman WB: Prolapsing neoplasms of the terminal ileum simulating enlarged ileocecal valves. AJR Am J Roentgenol 1980, 134:1133-1136.

34. Balamoun H, Doughan S: lleal lipoma - a rare cause of ileocolic intussusception in adults: case report and literature review. World $J$ Gastrointest Surg 2011, 3:13-15.

35. Namikawa T, Hokimoto N, Okabayashi T, Kumon M, Kobayashi M, Hanazaki K: Adult ileoileal intussusception induced by an ileal lipoma diagnosed preoperatively: report of a case and review of the literature. Surg Today 2012, 42:686-692.

36. Bilgin M, Toprak H, Ahmad IC, Yardimci E, Kocakoc E: lleocecal intussusception due to a lipoma in an adult. Case Rep Surg 2012 2012:684298

37. Hadithi M, Heine GD, Jacobs MA, van Bodegraven AA, Mulder CJ: A prospective study comparing video capsule endoscopy with double-balloon enteroscopy in patients with obscure gastrointestinal bleeding. Am J Gastroenterol 2006, 101:52-57.

doi:10.1186/1477-7819-12-143

Cite this article as: Kang et al:: Resolution of intussusception after spontaneous expulsion of an ileal lipoma per rectum: a case report and literature review. World Journal of Surgical Oncology 2014 12:143.

\section{Submit your next manuscript to BioMed Central and take full advantage of:}

- Convenient online submission

- Thorough peer review

- No space constraints or color figure charges

- Immediate publication on acceptance

- Inclusion in PubMed, CAS, Scopus and Google Scholar

- Research which is freely available for redistribution

Submit your manuscript at www.biomedcentral.com/submit
(O) Biomed Central 